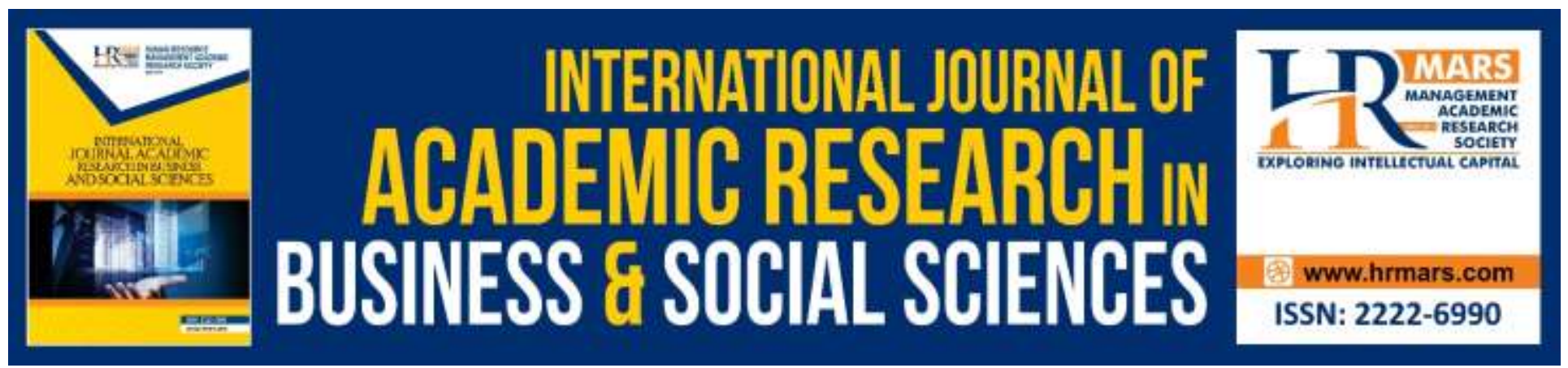

\title{
The Effectiveness of Talent Management Practice among Teachers in Malaysia
}

Noor Haslinda Harun, Nik Hasnaa Nik Mahmood, Siti Amirah Othman

To Link this Article: http://dx.doi.org/10.6007/IJARBSS/v9-i6/6072

DOI: $10.6007 /$ IJARBSS/v9-i6/6072

Received: 15 April 2019, Revised: 19 May 2019, Accepted: 04 June 2019

Published Online: 27 June 2019

In-Text Citation: (Harun, Mahmood, \& Othman, 2019)

To Cite this Article: Harun, N. H., Mahmood, N. H. N., \& Othman, S. A. (2019). The Effectiveness of Talent Management Practice among Teachers in Malaysia. International Journal of Academic Research in Business and Social Sciences, 9(6), 1104-1120.

\section{Copyright: (C) 2019 The Author(s)}

Published by Human Resource Management Academic Research Society (www.hrmars.com)

This article is published under the Creative Commons Attribution (CC BY 4.0) license. Anyone may reproduce, distribute, translate and create derivative works of this article (for both commercial and non-commercial purposes), subject to full attribution to the original publication and authors. The full terms of this license may be seen

at: http://creativecommons.org/licences/by/4.0/legalcode

Vol. 9, No. 6, 2019, Pg. $1104-1120$

http://hrmars.com/index.php/pages/detail/IJARBSS

JOURNAL HOMEPAGE

Full Terms \& Conditions of access and use can be found at http://hrmars.com/index.php/pages/detail/publication-ethics 


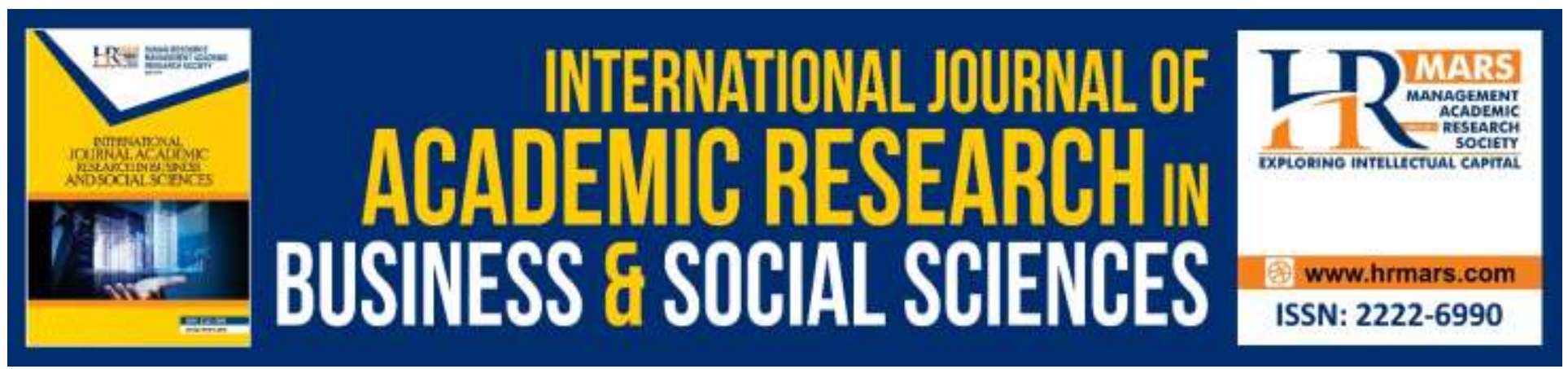

\title{
The Effectiveness of Talent Management Practice among Teachers in Malaysia
}

\section{Noor Haslinda Harun, Nik Hasnaa Nik Mahmood, Siti Amirah Othman}

Razak Faculty of Technology and Informatics, Universiti Teknologi Malaysia, 81310 UTM Kuala Lumpur, MALAYSIA.

E-mail: aslynda2329@gmail.com,nikhasnaa@live.utm, sitiamirahutm@gmail.com

\begin{abstract}
This paper is aimed to identify talent management practices among teachers in residential school. Talent management is a critical issue that need to be addressed promptly to overcomes competences idle. This study employed quantitative method. A total of 150 teachers has been selected as the respondents. Finding of this study showed that the level of talent identification and talent development is highest (mean score: 4.26 and 4.32) and talent culture level is high (mean sore: 4.18 ). The analysis on t-test for gender indicates that there is no difference between talent management and gender, its mean talent management is same for all whether man or women. There is statistically no significant difference between age, but only in the age between of 30 years to 39 years and 50 years above.
\end{abstract}

Keywords: Talent Management, Talent Identification, Talent Development, Talent Culture

\section{Introduction}

Talent management is triggered from the evolution of human resource management. It refers to a process of the progress of an industry which involves three levels. In early 19701980 , human resource management function is limited to personal management. It is most likely involving personnel department such as bonus and payroll for employee. While from the years of 1980 until 1990, most of the organizations have concerned about the role of the personnel department. Later, the initial concept of strategic management by human resources and the role of human resource manager increase to recruitment, employee development and compensation and more attractive incentives (Sneezing, 2006). Talent Management practices have developed and adopted through the years in response to many changes in the workplace from the industrial revolution to globalization (Sweem, 2009). The concept of talent management emerged in the late 1990s after the publication of the influential work 'war for talent' by McKinsey consultants (Micheals et al., 2001). 
Talent management is a set of human resources practices (Kesler, 2000; Schweyer, 2004; Sullivan, 2004). Talent management is nothing more than integrating traditional human resources practises. In the other hand, Lewis and Heckman (2006) also identify this conception of talent management practices. Both of them are argued that defining talent management as a collection of human resources practices may be a kind to a trendy term or a euphemism for human resources management. This is why talent management is often interpreted as a repacking of traditional human resources practices (Kabwe, 2011).

Talent management plays main focus on strategic management in terms of human resources in 20th centuries. The strategy highlights on how are the effectiveness and efficiency of process recruitment based on the skills. Talent management also develops managers and leaders in increasing values, culture and creates channels to form a leadership. In today's era, there is a need to identify the gap of existing skills among employees faster so that human resources can tailor made training efficiently. Talent management had also been highlighted in Mc Kinsey \& Company report. Furthermore, Michaels, Handfield Jones and Axelrod (2001) through his writing mentioned that talent management also connotes human resource management and leadership aspects. They also found that the average companies did better job in attracting, developing and retaining talented employees. Talent management taken a different form over the years does not only look at finding the best talent but also developing individuals.

Regarding Gay and Sim (2006), talent management as "facilitating the development and career progress of highly talented and skilled individuals in the organization, using formalised procedures resources, policies and processes. The talent management process focuses on developing employees and leaders for the future of the organization. Besides above-mentioned, talent is also defined as an ability of an employee which involve intuition, skills, knowledge, experience, judgement, attitude, and personality. There are a certain transition rules in determining the latest of human resource management. The tradition of human resources division is responsible for managing staff, payroll and incentives. In addition, employees also recruited differently such as to purchase employee. There is a different in terms of approach pertaining talent. It is undeniable managers play their roles in enhancing their employees talent. The employee been recruited such as advertised while attract potential employee to the organization. The new approach in talent management has also strengthened some development via work, training and monitoring. Furthermore, according to Michaels et al. (2001), employee involves in the latest talent management practice are different compared to their existing talents and skills.

Nonetheless, talent management in Malaysia is initially been introduced in the sector of GLC (Government -Linked Companies). In the beginning, it has been introduced to improve aspect of leadership development that focuses on leaders with experience and the ability to ensure the success of a business. Leadership development is also considered as a system in meeting the need of group leadership. Sometimes used to refer to corporate entities that may be private or public, which is listed on the stock exchange in which the government owns the importance of using a holding company. There are two main definitions of companies GLC which refer to the Government ownership (more 
than $50 \%$ ) while the second is the definition of the GLC refers to any corporate entity which has the government as the shareholder. According to GLC (2006). There are three key features that is taken into account in the construction of talent management model:

i. Leadership development must begin from the business strategy; in which all aspects of leadership development should focus on bringing the leaders who have the experience and ability required to achieve the unique business.

ii. Leadership development in an institution as a system and not merely the process; where every aspects of leadership development meeting the needs of the group leadership (leadership pool) you have selected.

iii. Collaboration between the management and the human resources division formed the entire leadership development.

\section{Problem Statement}

Talent management seems crucial since it becomes the master plan of teachers professional development. The Ministry Of Education (MOE) has utilised this model which adapted from a model Educator Talent management Framework (Sheratt et.al., 2013). MOE has realised the need for teachers to change from the tradition paradigm and cultivate the with lifelong education as highlighted in Malaysia Education Blueprint 2013-2025. Teachers should be more respond to change since it affects the global education system in Malaysia. Teachers needs a migration of mind whereby this will transform teachers hoe they think, how they communicate in oder to maintain high quality in education. In oder to expand the career path of teachers as well as playing a role of leadership, teaching expertise and specific areas in teachers talent management have been introduced in oder to improve the quality of education generally (MOE, 2016).

One of an effort to suppress the development of teacher professionalism is unproductive competency syndrome so called competency idle. Idle competency is a symptom that causes wastage and unbeneficial in terms of knowledge, skills, experience and talent in organization. This is due to the failure of principal in providing an opportunity for teachers to practice their skills and knowledge, inability of principal in giving attention to the teachers namely in the field of recognising talent, skills, delegation of duties, and inability to understand teachers which becomes one of the major reason of this syndrome. Therefore this study tends to identify the talent management level in school.

On the contrary, age factor also is considered as one of the problem in improving talent management among employees (says who???). These problems cabe seen when those group with old age are to be more prominent with many years work experience than the young group. Young people are seen lack of knowledge and experience in management and development which causes a problem in term of a talented born employee. When those senior employees retired, it will be replaced with young 
people with lacking of skills in managing organizations (Siti \& Azman, 2013). Furthermore, according to Sathiyabama (2017): Azlin (2017) and Shuhaida, (2016) there is a lack of study in the issue of talent management in the education field in Malaysia.

\section{Research Objectives}

The objectives of this study are as follow:

i. To identify levels of talent management in terms of talent identification, talent development and talent culture

ii. To identify the most dominant dimensions of talent management among teachers

iii. To identify the differences of teacher talent management based on gender

iv. To identify the differences of teacher talent management based on age

\section{Model of Talent Management}

There are many talent management model use by organization. One of the model is By Grooves (2007)

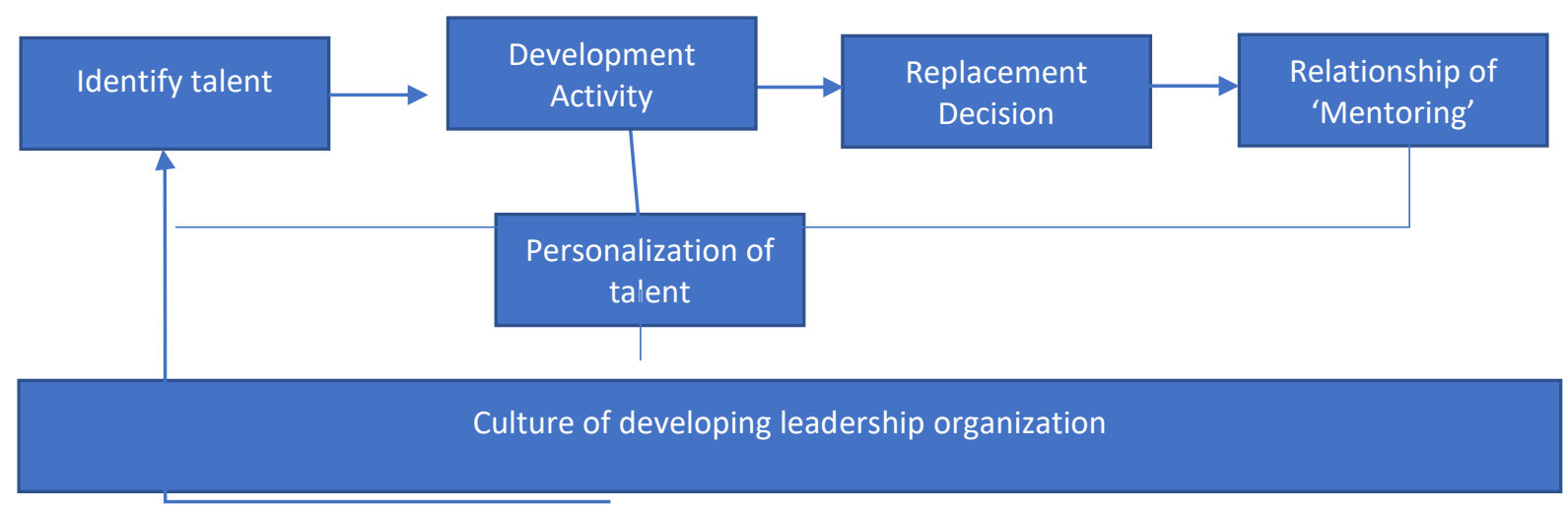

Figure 1: $\quad$ Model Talent Management Groves (2007)

According to this model, the organizations need to identify and develop talented employees. Besides playing a key role in developing an effective mentor network, manager also need to be actively involved in identifying leadership talent throughout the organization. Although the methods and tools for the afore mentioned purpose are varying in the organization, there are two similar themes emerged that avoid finding replacement for succession planning. This can be done by adopting long term perspective. By doing this it can identify and develop leadership talent from within the 
INTERNATIONAL JOURNAL OF ACADEMIC RESEARCH IN BUSINESS AND SOCIAL SCIENCES

Vol. 9, No. 6, June, 2019, E-ISSN: 2222-6990 @ 2019 HRMARS

organization as well as and having full involvement of management staffing in the process of identifying talent. Based on this model, one more feature of succession planning system is to focus on the activity of orientation action development

\section{Literature Review}

Ingham (2006) states that there is no universal definition that can define the real meaning of talent management since each organization has their own definition of talent management. Nonetheless, Brandt (2011) defines that talent management as a strategy in improving performance among teachers and school administrators. A quantitative study by Norsaidi (2018) on total of 280 lectures at the public university in Malaysia found that talent management has a significant relationship on employee retention. This finding also revealed that organizational culture affect the partial intermediary in relation between the minds of talent management, pride of the organization, strategic acquisition and strategic development towards employee retention. The research model was constructed and tested using IBM Statistical Package for social Science (SPSS) AMOS. Regression analysis was used to test the hypothesis of this study. The multiple regression revealed that organizational culture has a full mediator effect in the relationship between strategic recruitment and employee retention.

The concept of talent management expanding when the appearance of competitive among organization to get talented employees. Talent management evolved in mid 1990s and increasingly wide spread around the earlier of the $21^{\text {st }}$ century. According to Lewis and Heckman (2006), talent management is an integral part of human resources management and it is very difficult to identify it accurately. This is due to many confusing results among researchers pertaining talent management definitions. A study conducted by Shuhaida (2016) revealed that there are five component of talent management namely identifying potential teachers, performance checking, developing teachers, using the teachers' talent and retaining them by developing leadership talent is at the satisfy level. The five components do contribute to developing leadership talent among teachers. The study was contribute to developing leadership talent among teachers. The study was conducted over 35 high performing secondary schools across the country which involving a total of 400 teachers as respondents. The study used mixed methods by carried out an interview and survey.

In another study by Siti and Azman (2013), that focuses on relationship between talent management and work performance found that talent management can improve work performance. The study is carried out in the Islamic banking sector in Malaysia by using qualitative study. An interview has been conducted on ten responden from the Islamic banking in Malaysia. The finding also contributes to body of knowledge namely training and additional skills. Furthermore, the participation of employee in the talent management has increased their performance and enhance the reputation of organization. The study also beneficial to practitioners, whereby the findings can be used as a guideline to the managers in having further understanding on the complexity of talent management especially in developing a strategic plan as a push factor for the employees to achieve organizational goals. 
Further research was done by Yong, Shahimi and Ahmad (2017) on the effectiveness of talent management in improving organizational performance of Bank Simpanan Nasional, This conceptual research focused on the employee attraction, retention, motivation and development of succession planning. While the performance variables in this study are sales growth rate, the products operation and human resources products. It is found that talent management develops employees or create a succession plan. Talent management goals are more common, but the important mission in talent management is to help the entire of organization and the objectives at minimum cost by having talented workers. Another study by Noramy (2014), found that there are several factors which affect talent management, such as career management, performance and factors of learning and development. Career management is the most dominant factor in affecting talent management. This study was carried out on 144 bank workers in Alor Setar by using questionnaire. Talent management in this study involves the process of attracting, developing, maintaining and using talents within the organization. This study used regression as an analysis.

According to Pella and Afifah (2011), talent management is defined as a process of comprehensive and dynamic in expanding a group of human potential in organization through the development of integration. It is practised by leaders in the organization to the talented employees by selected them and developing their talents. In addition, according to Pella and Afifah (2011), the development of mind set is among the characteristics of talent management. Secondly, the characteristics of talent management is the implementation of excellent work culture. By implementing talent management program, organization can identify the indicators of excellent work culture. This can achieved by evaluating the success of employee. Subsequently, the organization entails an active human resources manager who is always thinking to produce talented workers and retain talented employees. A good manager will also provide coaching, education, training for candidates of future leaders. Finally, an organization needs to implement a culture of helping in managing the talent of employees. Therefore, organizations needs to have good infrastructure, especially in term of information technology.

A study by Omar, Anuar, Majid and Johari (2012) found that there is a significant relationship Between employee training and development in increasing the retention of talented employees in an organization. This indicated the strengths of organization in training and development of employee. It enhances talent management of employees and turns the employees to be more loyal to the organization. According to Amstrong (2006), talent management is a process of talent identification, expanded talent, recruiting talented employees and helping employees develop their talents. In fact, Simalango in Ratno (2011) explains that the talent management is a process of human resources management which related to the three processes namely developing and improving new employees, retaining and developing the existing employee and ultimately attracting as much as possible employees who have competency, commitment and determination to work in the organization. In this study, the talent management also looks on how an organization identify the school teacher's talent, develop their talent and promote the talent among the school community. 


\section{Talent Management Dimension Talent Identification}

Talent identification is a processes and activities to determine and searching for talent (Azlin, 2017). An organization need to focus on the necessity to be successful and fulfil employees specific role by identifying potential talented employee (Davies and Davies, 2010). This involved an identification of talent by looking at performance evaluation and potentiality of teacher. To identify, develop and get the best out of people is vital for any organization. To identify people who are doing a great job in their present role and how to help them develop their potential is avital process for the management of talent (Davies and Davies, 2011).

\section{Talent Development}

Talent development are requires a clearly defined structure of leadership roles which grow in responsibility and impact. A talent development process needs a clear understanding about the characteristic and behaviors associated with success at each level of leadership. This may involve letting a talented leader leave if there are no appropriate opportunities in the school through which to challenge and develop them (Davies and Davies, 2011). According to Dongen (2014), the process of talent development focuses on the development of specific capabilities or competencies that expected to be required by the organization in the future. The ability or efficiency is part of the development of strategic organization. In this study, the talent development process involves talent development, professional learning and the architecture to support to support talent development.

Research doing by The NCSL (2008) are suggested the planning of talent development should focuses on leadership behaviour likely have most impact on a pupils learning, provides clear expectations for everyone involves in the programme, needs of potential leaders in the different phase of education and allows for personalisation.

\section{Talent Culture}

Talent culture in this study means retaining the existing teachers. According to Deb (2012), retaining employees is a systematic effort to create and foster a work environment that encourages them to remain and with organizational policies and practices that can address their needs. This can cultivate the culture of talent management system as a whole. Culture is about the values, about shared beliefs, about purpose and about relationship. Our model for the dimensions of leadership also identifies the important aspects for developing an effective culture for talent development which is the culture where the value of trust and respect are at the heart of the organization and seen in action, not just rhetorical statement a culture where teamwork and sense of community thrive (Davies and Davies, 2011).

\section{Methodology}

This study employs quantitative survey. Objective of this study was to identify the level of talent management among teachers and searching the most dominant dimension of talent management. The findings of this research is based on the perception of teachers by looking at the level of their talent management in school. 


\section{The Samples}

The sample of this study involved a total of 150 teachers in residential schools. The years of teaching is more than a year and the tenure of service admin of the principal is more than a year as well as recommended various scholars (Bass, 1995: Kingstrom and Mainstrone, 1985).

\section{Instrument}

The instrument distributed to teachers is adopted and adapted by the researcher based on Davies and Davies (2010). Talent Education by Davies and Davies (2010) clarifies closer deep approach and closely related to education context in school. Based on literature review, it also indicates that there are not many studies in talent management in education (Sathiyabama, 2017; Shuhaida, 2016)

\section{The Validity of the Questionnaire}

Researcher has asked five experts in the talent management field. All appointed expert are based on their expertise in the field of talent management and educational leadership management. The researcher gave the rubric verification questionnaire (Survey Validation Rubric for Expert PanelVREP). According to Lynn (1986) the questionnaire requires a minimum number of three expert and not more than ten expert.

\section{Reliability Survey}

The researcher also looking at the Cronbach alpha test. The coefficient range between 0.834 to 0.53 is consider satisfactory. The alpha Cronbach value for each variable was shown as a table 1 below. All values indicate a satisfactory level of reliability.

Table 1: Results of Cronbach alpha per dimension value

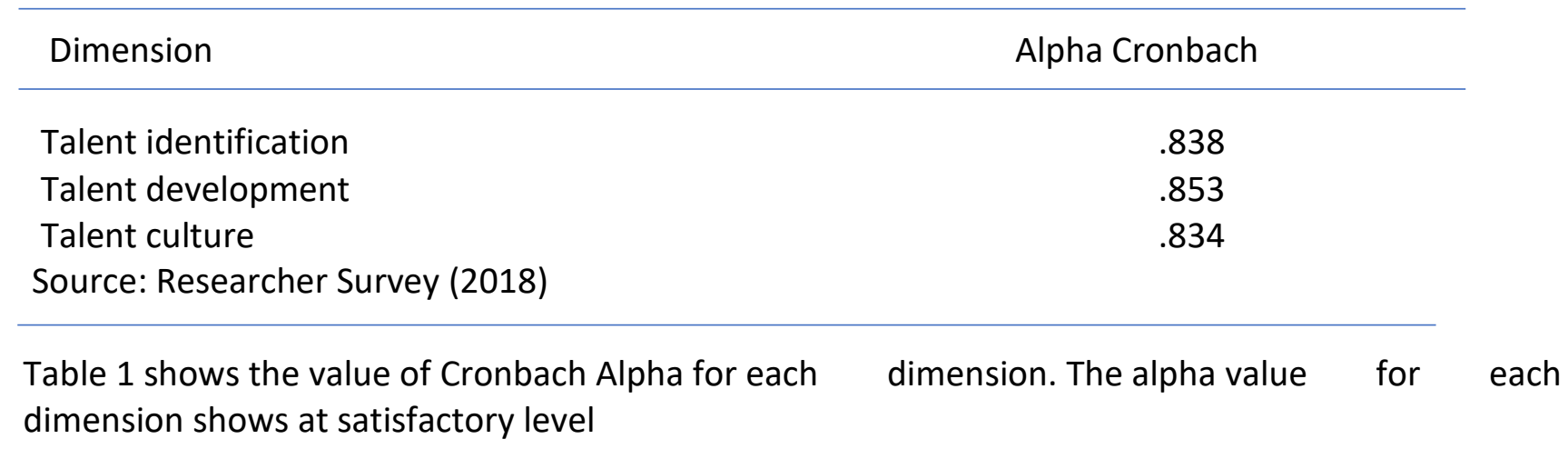


INTERNATIONAL JOURNAL OF ACADEMIC RESEARCH IN BUSINESS AND SOCIAL SCIENCES

Vol. 9, No. 6, June, 2019, E-ISSN: 2222-6990 (C) 2019 HRMARS

The Table below depicts the dimension of talent management and number of items for each dimension.

Table 2: Levels of talent management

\begin{tabular}{llc}
\hline Dimension & & Number of item \\
\hline Talent identification & Performance evaluation & 6 \\
& Potential & 6 \\
\hline Talent development & Development of talent & 4 \\
& Learning Professional & 4 \\
& Supporting of talent development & 4 \\
\hline Talent culture & Cultivate of talent culture & 6 \\
& System of talent culture & 7 \\
\hline Total item & & 37 \\
\hline
\end{tabular}

From the table 2 above, the dimensions of talent management are divided into three dimensions which contain 37 items. Talent identification comprises six item of performance evaluation and six item for potential. For the dimension of talent development it comprised to four item for development of talent, four item for learning profesional and four item for supporting of talent development. Total item for talent development is 12 item. On the other hand, talent culture consists six item for cultivate of talent culture and seven item for system of talent culture.

\section{Data Analysis}

Data is analysed by using IBM SPSS version 23 using descriptive and inferential statistics as follows.

\section{Findings}

Table 3: Respondent demographics by gender, age, academic qualifications and experience

\begin{tabular}{llcc}
\hline & Category & Number of respondent & Percent \\
\hline \multirow{2}{*}{ Gender } & Male & 50 & 33.3 \\
& Female & 100 & 66.7
\end{tabular}

$\mathrm{n}=150$

From the above table, 33.3 per cent is male respondent, while women responden amounted 66.7 per cent which represent 100 persons from respondents. This is common with majority are women in school. 
INTERNATIONAL JOURNAL OF ACADEMIC RESEARCH IN BUSINESS AND SOCIAL SCIENCES

Vol. 9, No. 6, June, 2019, E-ISSN: 2222-6990 @ 2019 HRMARS

Table 4: Respondent demographics by age

\begin{tabular}{|c|c|c|c|}
\hline & Category & Number of respondent & Percent \\
\hline \multirow[t]{4}{*}{ Age } & $20-29$ & 6 & 4 \\
\hline & $30-39$ & 20 & 13.3 \\
\hline & $40-49$ & 72 & 48.0 \\
\hline & 50 above & 52 & 34.7 \\
\hline
\end{tabular}

$n=150$

Most of the respondents age is between 40-49 years, which represents 48 percent of the respondents. While teachers with age 50 years and above amounted to 52 people representing 34.7 percent. This mean the number of respondents with age 40 years and above is more than 50 percent. This shows that the talent management among teachers are easy to be implemented.

Table 5: Respondent demographics by qualifications

\begin{tabular}{lccc}
\hline & Category & Number of respondent & Percent \\
\hline \multirow{2}{*}{ Qualification } & Bachelor Degree & 128 & 85.3 \\
& Master & 22 & 14.7 \\
\hline
\end{tabular}

85.3 percent indicated that the respondents hold the first degree, followed by 14.7 percent have a master degree

Table 6: Respondent demographics by experience

\begin{tabular}{|c|c|c|c|}
\hline & Category & Number of respondent & Percent \\
\hline \multirow[t]{5}{*}{ Experience } & $1-5$ years & 4 & 2.7 \\
\hline & $6-10$ years & 9 & 6.0 \\
\hline & $11-15$ years & 63 & 42.0 \\
\hline & $16-20$ years & 38 & 25.3 \\
\hline & 21 years above & 36 & 24.0 \\
\hline
\end{tabular}

$\mathrm{n}=150$

In terms of work experience, 49.3 percent of the teachers have experienced over 15 years. There are only 8.7 percent of teachers are experienced less then 10 years. This indicates that almost half of the teachers has a expertise in their respective fields in school. 
INTERNATIONAL JOURNAL OF ACADEMIC RESEARCH IN BUSINESS AND SOCIAL SCIENCES

Vol. 9, No. 6, June, 2019, E-ISSN: 2222-6990 @ 2019 HRMARS

To Identify Levels of Talent Management in Terms of Talent Identification, Talent Development and Talent Culture

The findings of this study in terms of level teachers' talent management are described as below basing on talent identification, talent development and talent culture.

Table 7: Results of the mean score for each dimension of talent management

\begin{tabular}{lrcc}
\hline Dimension & Min Score & Standard Deviation & Level \\
\hline Identification of talent & 4.26 & .367 & Highest \\
Development of talent & 4.32 & .358 & Highest \\
Talent culture & 4.18 & .270 & High
\end{tabular}

Table 4 shows the dimension of talent management is at very high level. Types of talent identification has mean score of 4.26 (highest). Followed by talent development which is score mean 4.32 (highest). The mean score for talent culture at 4.18 (high). This indicates the principal of each school is aware of the importance of talent management for teachers in their school. The mean value of the scores obtained from descriptive statistics can be divided into five level (Rosnani, 2014) as in table below:

Table 8: Mean score of talent management

\begin{tabular}{ll}
\hline Mean Score & Level \\
\hline $1.00-1.80$ & Lower \\
$1.81-2.60$ & Low \\
$2.61-3.40$ & Medium \\
$3.41-4.20$ & High \\
$4.21-5.00$ & Highest \\
\hline
\end{tabular}

Source: Rosnani (2014)

The Most Dominant Dimensions of Talent Management among Teachers

Based on the table 4 above, it is found that teachers talent development dimension has a mean value of 4.32 and it indicates that talent development is the most dominant dimension. This portrays that talent development has an impact in talent management which includes training in improving professionalism of teachers. 
INTERNATIONAL JOURNAL OF ACADEMIC RESEARCH IN BUSINESS AND SOCIAL SCIENCES Vol. 9, No. 6, June, 2019, E-ISSN: 2222-6990 (C) 2019 HRMARS

The Differences of Teachers Talent Management Based on Gender

Table 9: T-test for gender

Independent Samples Test

\begin{tabular}{|c|c|c|c|c|c|c|c|c|c|}
\hline & \multicolumn{2}{|c|}{$\begin{array}{l}\text { Levene's } \\
\text { Test for } \\
\text { Equality of } \\
\text { Variances }\end{array}$} & \multicolumn{7}{|c|}{ t-test for Equality of Means } \\
\hline & \multirow[b]{2}{*}{$\mathrm{F}$} & \multirow[b]{2}{*}{ Sig. } & \multirow[b]{2}{*}{$\mathrm{t}$} & \multirow[b]{2}{*}{ df } & \multirow{2}{*}{$\begin{array}{l}\text { Sig. (2- } \\
\text { tailed) }\end{array}$} & \multirow{2}{*}{$\begin{array}{l}\text { Mean } \\
\text { Differ } \\
\text { ence }\end{array}$} & \multirow{2}{*}{$\begin{array}{l}\text { Std. Error } \\
\text { Difference }\end{array}$} & \multicolumn{2}{|c|}{$\begin{array}{l}95 \% \\
\text { Confidence } \\
\text { Interval of the } \\
\text { Difference }\end{array}$} \\
\hline & & & & & & & & Lower & Upper \\
\hline $\begin{array}{l}\text { Equal } \\
\text { variances } \\
\text { assumed }\end{array}$ & $\begin{array}{l}11.3 \\
56\end{array}$ & .001 & .762 & 150 & .447 & 1.270 & 1.667 & -2.023 & 4.563 \\
\hline $\begin{array}{l}\text { Equal } \\
\text { variances } \\
\text { not assumed }\end{array}$ & & & .856 & $\begin{array}{l}132.12 \\
5\end{array}$ & .394 & 1.270 & 1.484 & -1.666 & 4.206 \\
\hline
\end{tabular}

As referred to table 9, it indicates that there is no significant different between gender and talent management for two groups $(t=.762$, $d f=150, p<.005)$.

The Differences of Teachers talent Management Based on Age

ANOVA test for age

\section{ANOVA}

Table 10: ANOVA test for age

\begin{tabular}{|l|l|l|l|l|l|}
\hline & $\begin{array}{l}\text { Sum of } \\
\text { Squares }\end{array}$ & df & $\begin{array}{l}\text { Mean } \\
\text { Square }\end{array}$ & F & Sig. \\
\hline $\begin{array}{l}\text { Between } \\
\text { Groups } \\
\text { Within } \\
\text { Groups } \\
\text { Total }\end{array}$ & 1042.019 & 3 & 347.340 & 3.989 & .009 \\
\hline
\end{tabular}


INTERNATIONAL JOURNAL OF ACADEMIC RESEARCH IN BUSINESS AND SOCIAL SCIENCES

Vol. 9, No. 6, June, 2019, E-ISSN: 2222-6990 @ 2019 HRMARS

\section{Multiple Comparisons}

\begin{tabular}{|c|c|c|c|c|c|c|}
\hline \multirow[b]{2}{*}{ (I) AGE } & \multirow[b]{2}{*}{ (J) AGE } & \multirow{2}{*}{$\begin{array}{l}\text { Mean } \\
\text { Differen } \\
\text { ce (I-J) }\end{array}$} & \multirow[b]{2}{*}{$\begin{array}{l}\text { Std. } \\
\text { Error }\end{array}$} & \multirow[b]{2}{*}{ Sig. } & \multicolumn{2}{|c|}{$\begin{array}{l}95 \% \text { Confidence } \\
\text { Interval }\end{array}$} \\
\hline & & & & & $\begin{array}{l}\text { Lower } \\
\text { Bound }\end{array}$ & $\begin{array}{l}\text { Upper } \\
\text { Bound }\end{array}$ \\
\hline \multirow[t]{3}{*}{20 to 29 years } & 30 to 39 years & 2.117 & 4.344 & .962 & -9.17 & 13.40 \\
\hline & 40 to 49 years & 7.444 & 3.965 & .242 & -2.86 & 17.75 \\
\hline & $\begin{array}{l}50 \text { years and } \\
\text { above }\end{array}$ & 9.224 & 4.023 & .104 & -1.23 & 19.68 \\
\hline \multirow[t]{3}{*}{30 to 39 years } & 20 to 29 years & -2.117 & 4.344 & .962 & -13.40 & 9.17 \\
\hline & 40 to 49 years & 5.328 & 2.359 & .113 & -.80 & 11.46 \\
\hline & $\begin{array}{l}50 \text { years and } \\
\text { above }\end{array}$ & $7.108^{*}$ & 2.455 & & & 13.49 \\
\hline \multirow[t]{3}{*}{40 to 49 years } & 20 to 29 years & -7.444 & 3.965 & .242 & -17.75 & 2.86 \\
\hline & 30 to 39 years & -5.328 & 2.359 & .113 & -11.46 & .80 \\
\hline & $\begin{array}{l}50 \text { years and } \\
\text { above }\end{array}$ & 1.780 & 1.698 & .721 & -2.63 & 6.19 \\
\hline \multirow{3}{*}{$\begin{array}{l}50 \text { years and } \\
\text { above }\end{array}$} & 20 to 29 years & -9.224 & 4.023 & .104 & -19.68 & 1.23 \\
\hline & 30 to 39 years & $-7.108^{*}$ & 2.455 & .022 & -13.49 & -.73 \\
\hline & 40 to 49 years & -1.780 & 1.698 & .721 & -6.19 & 2.63 \\
\hline
\end{tabular}

*. The mean difference is significant at the 0.05 level.

According to Table 10 and 11, they exhibit that there are statistically significant difference in the mean for the four difference between age in talent management.

\section{Discussion and Summary}

Talent management is one of the key strategies to ensure leaders are trained in a way that the most efficient and placed at the right place and the right people as needed (Blass, 2007: Gender, 2008 : Ford, 2010). In the context of this study, if a teacher is given a chance to improve career and professional development, eventually they will be more enthusiastic in their work. This will indirectly improve the quality of teachers and the excellence performance of the teacher through the school. Talent management is to choose the right people, work appropriate to the culture and at the right time (Tarique, Ibraiz, and Randall, Schuler, 2010). In the opinion of Jensen (1976) and Schiemann (2014) believe that the central aim and effort of talent management is to seek, develop and intelligently utilizes excellent capabilities and fulfills high potential for long-term optimum business and individual benefits. Wright (2006) believes that talent management is the strategic management of talent flows through the organization. Schweyer, Allan (2010) states that talent management for some people, is a set of practices to ensure the sustainability of talented employees into roles throughout the organization. Every stage in the administration is the key to managing talents and achieving good performance in order to gain competitive advantage for an organization (Coperland 
and Mary kay, 2014). Hence, in order to gain competitive advantage, demand for human capitaldriven talent needs to persist (Perrine, 2005)

According to Perrin, and Gardner (2009), this talent management is a challenge for organizations in the context of globalization towards the country. In addition, to gain competitive advantage, it also comes from talent management where the organization draws, expands, retains, motivates in managing existing talents. An organization should also look back at the talent management that have been used and rethink the new approach to talent management to strengthen their position in today's global economy. According to Ashton, Chris, and Lynne Morton (2005), this fact is reinforced by the affirmation by Frank, F.D. and Taylor (2004) where working stress patterns such as demographic changes, global supply chains, and rising global mobility levels require new and better talent management.

\section{Reference}

Ashton, C. and Morton, L. (2005). "Managing talent for competitive advantage: Taking a systemic approach to talent management." Strategic HR Review 4, no. 5: 28-31

Azlin, A., Z., Mansor, A. M. \& Wahab, J. A. (2017). Amalan Pengurusan Bakat sekolah Menengah Kebangsaan Agama, Selangor Malaysia. Jurnal Pendidikan UKM

Bass, B. M. (1985). Leadership and performance beyond expectations. New York: The Free Press

Bersin, J. (2006). Talent management; What is it? Why now?

From http:www.astdla.org/resources/document/websitedocument/ keyrefrencearticle.pdf

Brandt, J. (2011). Transforming education with talent management. School Business Affair http:// www.cornerstoneonedemand.com/assets/pdf/sba_article.pdf

Blass, E. (2007) Talent management: Maximising for future performance. London:Chartered Management Institute. www.managers.org.uk/sites/default/Talent Management

Copeland, M. K. (2014). "The emerging significance of values based leadership: a literature review." International journal of leadership studies 8, no. 2): 105-135.

Davies, B., \& Davies, B. J. (2010). Talent management in academics. International Journal of Education Management. 24(5): 418-426

Davies, B., \& Davies, B. J. (2011). Talent management in education. London: Sage Publication Ltd.

Deb, T. (2012). Managing Human Resources and Industrial Relations. New Delhi: Excel Books

Frank, F. D., and Craig, R. T. (2004). "Talent management: Trends that will shape the future." People and Strategy 27, no. 1:33.

Gay, M., \& Sims, D. (2006). Building tomorrow's talent: A practitioners guide to talent management and succession planning. Bloomington, IN: Author house.

Groves, K. S. (2007). Integrating leadership development and succession planning best practises. Journal of Management Development. 26(3):239-260

GLC. (2006). The Orange book: Strengthening leadership development. Putrajaya: Putrajaya Committee on GLC high Performance (PCG)

Ingham, J. (2006). Closing the talent management gap. Harnessing your employee's talent to deliver optimum business performance. Strategic HR Review, 5(3), 20-23. 
Jensen, M. C., and William, H. M. (1976). "Theory of the firm: Managerial behavior, agency costs and ownership structure." Journal of financial economics 3, no. 4 :305-360.

Kamil, B. A. M., Hamid, Z. A., Hashim, J., \& Omar, A. (2010). A study on the implementation of talent management practices at Malaysian companies. Asian Journal of Business and Management Sciences, 1(4), 147-162.

Kementerian Pendidikan Malaysia. (2013). Pelan Pembangunan Pendidikan Malaysia 2013- 2025 (Pendidikan Prasekolah hingga Lepas Menengah). Putrajaya: Kementerian Pendidikan Malaysia

Kingstrom, M. S. O., \& Mainstone, L. E. (1985). An investigation of the rater-ratee acquaintance and rater bias. The Academy of Management journal 28(3), 641-653

Lewis, R. E., \& Heckman, R. J. (2006). Talent management: A critical Review. Human Resources management Review. 16:139-154

Lynn, M. R. (1986). Determination and qualifications of content validity. Nursing Research. 35:382385

Michaels, E., Handfield-Jones, H., \& Axelrod, B. (2001). The war for talent: Harvard Business Review Press

Omar, K., Anuar, M. M., Majid, A. H. A., Dan Johari, H. (2012). Organizational Commitment And Intention To Leave Among Nurses In Public Hospitals. International Journal Of Business and Social Science, 3(16).

Rosnani, K. (2014). Pengaruh Kepimpinan Pengetua \& Amalan Pengurusan Kualiti Menyeluruh(TQM) terhadap Kepuasan Kerja serta Komitmen Guru . Tesis PhD tidak diterbitkan. Universiti Utara Malaysia

Sathiyabama, S., Sathiyamoorthy, K. \& Chua, Y. P. (2016). Pengurusan Bakat dalam kalangan Graduan Program Kelayakan Profesional Kebangsaan bagi Pemimpin Pendidikan (NPQEL). Educational Leader. Vol 4, page $66-77$.

Sathiyabama, S. \& Sathiamoorthy, K. (2016). Hubungan antara Bakat Kepimpinan, Kepimpinan Halatuju sekolah Graduan Program Kelayakan Profesional Kebangsaan bagi Pemimpin Pendidikan (NPQEL). Jurnal Kepimpinan Pendidikan. Bil 3 isu 2: 24-41

Sathiyabama, S. (2017). Bakat Kepimpinan, Kepimpinan Halatuju sekolah Graduan Program Kelayakan Profesional Kebangsaan bagi Pemimpin Pendidikan (NPQEL). Tesis PhD Universiti Malaya

Schiemann, W. A. (2014) "From talent management to talent optimization." Journal of World Business 49, no. 2: 281-288.

Schweyer, A. (2010) Talent management systems: Best practices in technology solutions for recruitment, retention and workforce planning. John Wiley \& Sons.

Shuhaida, S. (2016). Pengurusan Bakat di sekolah berprestasi Tinggi di Malaysia. Tesis PhD tidak diterbitkan. Universiti Kebangsaan Malaysia.

Ghazali, S. Z. M., \& Ismail, M. (2008). Kaitan antara Latihan Pengurusan Bakat dengan Prestasi kerja dalam Sektor Pebankan Islam. Prosiding PERKEM VIII Jilid 1 (2013) 101-111

Sweem, S. L. (2009). Leveraging Employee Engagement through a Talent Management Strategy: Optimizing Human Capital through Human Resources and Organizing Development Development Strategy in a Field Study. Pro Quest, UMI Disertation Publishing 
Noramy, S. S. T. A. (2016). Faktor-faktor yang mempengaruhi Pengurusan Bakat di Sektor Perbankan Islam di Alor Setar. Tesis Sarjana tidak diterbitkan. Universiti Utara Malaysia.

Pallant, J. (2013). SPSS Survival Manual: A Step By Step Guide To Data Analysis Using IBM SPSS (5th ed.). New York: McGraw-Hill.

Perrine, P. (2005). "Integrating talent management." Human Resources Management 36, no. 2

Perrin, T. (2009). "Employee engagement underpins business transformation."

Wright, R. (2006). "The strategic value of people: Human resource trends and metrics." Conference Board of Canada. 